\title{
HUBUNGAN ANTARA FAKTOR KESELAMATAN BERKENDARA DENGAN PERILAKU KESELAMATAN BERKENDARA
}

\section{RELATIONSHIPS BETWEEN SAFETY RIDING FACTORS WITH SAFETY RIDING BEHAVIOUR}

\author{
Nova Mega Muryatma \\ Derpartemen Promosi Kesehatan dan Ilmu Perilaku, \\ Fakultas Kesehatan Masyarakat, Universitas Airlangga, Surabaya. \\ Email :www.novamega@gmail.com
}

\begin{abstract}
Surabaya is the capital city of East Java Province and is a large city with a population of 2,807 inhabitants. According to WHO in 2011 showed that 400,000 victims under the age of 25 who died on the highway, with an average mortality rate of 1,000 children and adolescents each day. The cause of the greatest accidents is caused by human factors that do not apply discipline in traffic, low awareness, and lack of knowledge about safety riding. The purpose of this study is to analyze the relationship between safety factor driving with saefty riding behavior on students of SMK PGRI 4 Surabaya. This research is an observational analytic research using research method with cross sectional design. The sample of 74 respondents was taken randomly using simple random sampling technique. Data collection using questionnaires tool filled by respondents. Data analysis in this study using Chi Square test with 5\% significance value to see the relationship between independent variables with dependent variable. Based on the research conducted there is no significant relationship between independent variables with dependent variable with p-value exceed the value of meaning. In order to minimize the incidence of traffic accidents involving students it is good that schools always do the provision of a bound regulation that students are required to use SNI helmets when riding a motorcycle, no need to use expensive helmet but just use a helmet that complies with safety standards. Facilities for students are expected to always comply with existing traffic rules while driving.
\end{abstract}

Keyword: safety riding, student, safety riding behaviour

\begin{abstract}
Abstrak: Surabaya merupakan ibu kota Provinsi Jawa Timur dan merupakan kota besar dengan jumlah penduduk 2,807 jiwa. Data WHO tahun 2011 menunjukkan sekitar 400.000 korban di bawah usia 25 tahun yang meninggal di jalan raya, dengan rata-rata angka kematian 1.000 anak dan remaja setiap harinya. Penyebab kecelakaan paling besar disebabkan oleh faktor manusia yang tidak menerapkan disiplin dalam berlalu lintas, rendahnya kesadaran, dan minimnya pengetahuan akan keselamatan berkendara. Tujuan dari penelitian ini adalah menganalisis hubungan antara faktor keselamatan berkendara dengan perilaku keselamatan berkendara pada pelajar SMK PGRI 4 Surabaya. Penelitian ini merupakan penelitian observasional analitik yang menggunakan metode penelitian dengan desain cross sectional. Sampel penelitian sebesar 74 responden diambil secara acak menggunakan teknik pengambilan sampel simple random sampling. Pengumpulan data menggunakan alat bantu kuesioner yang diisi oleh responden. Analisis data pada penelitian ini menggunakan uji Chi Square dengan nilai kemaknaan 5\% untuk melihat hubungan
\end{abstract}


antara variabel bebas dengan variabel terikat. Berdasarkan penelitian yang dilakukan tidak ditemukan adanya hubungan yang signifikan antara variabel bebas dengan variabel terikat dengan p-value melebihi nilai kemaknaan. Guna meminimalisir kejadian kecelakaan lalu lintas yang melibatkan pelajar ada baiknya sekolah selalu melakukan pemberian peraturan yang terikat bahwa pelajar diwajibkan menggunakan helm SNI saat mengendarai sepeda motor, tidak perlu menggunakan helm mahal tetapi cukup menggunakan helm yang sesuai standar keamanan. Sarana untuk pelajar diharapkan untuk selalu mematuhi peraturan lalu lintas yang ada saat berkendara.

Kata Kunci: keselamatan berkendara, pelajar, perilaku keselamatan berkendara

\section{PENDAHULUAN}

Data WHO (2011) menunjukkan bahwa sebanyak $67 \%$ korban kecelakaan lalu lintas berada pada usia produktif yaitu pada usia 22 sampai dengan 50 tahun. Terdapat sekitar 400.000 korban di bawah usia 25 tahun yang meninggal di jalan raya, dengan rata- rata angka kematian 1.000 anak dan remaja setiap harinya. Kecelakaan lalu lintas menjadi penyebab utama kematian anak di dunia, dengan dengan rentang usia 10 sampai dengan 24 tahun. (Badan Intelejen Negara, 2012)

Surabaya merupakan Ibu kota dari Provinsi Jawa Timur. Berdasarkan data dari Badan Pusat Statistik (2012) korban kecelakaan lalu lintas pada tahun 20017 adalah 49.553 jiwa dan meningkat pada tahun 2010, korban kecelakaan menjadi 66.488 jiwa, dengan korban meninggal sebanyak 19.873 jiwa, luka berat sebanyak 26.196 jiwa. Berdasarkan data tersebut maka ada 54 orang yang meninggal akibat kecelakaan lalu lintas setiap harinya atau dengan kata lain 26 menit terdapat 1 orang meninggal dunia.

Berdasarkan data Satlantas Polres Kota Surabaya (2014) pelajar menjadi penyumbang terbanyak dalam kecelakaan.

Tabel 1. Data Kecelakaan Lalu Lintas Pelajar

\begin{tabular}{l|c}
\hline Data Laka Lantas & Pelajar \\
\hline Meninggal & 25 \\
Luka Berat & 22 \\
Luka Ringan & 114 \\
\hline Jumlah Laka & 161 \\
\hline
\end{tabular}

Sumber : Data Sekunder Satlantas Polres

Kota Surabaya
Berdasarkan data Satlantas menerangkan bahwa jumlah kecelakaan yang melibatkan pelajar adalah 161 kejadian. Data membuktikan bahwa tahun 2014 sampai dengan tahun 2015 di jalan Ir.Soekarno Kota Surabaya saja telah terjadi 161 kecelakaan lalu lintas yang melibatkan pelajar dan korban meninggal sebanyak 25 orang, luka berat 22 orang dan luka ringan sebanyak 114 orang. Angka tersebut bukanlah angka yang sedikit oleh karena itu pentingnya perilaku keselamatan berkendara remaja untuk meminimalisir terjadinya kecelakaan lalu lintas yang melibatkan pelajar.

Beradasarkan UU RI No 22 Tahun 2009 tentang Lalu Lintas dan angkutan jalan, penyebab kecelakaan lalu lintas salah satunya disebabkan oleh sepeda motor dapat diklarifikasi menjadi empat faktor yaitu, kelalaian dari pengguna jalan, ketidaklayakan kendaraan, ketidaklayakan jalan dan lingkungan.

SMK PGRI 4 Surabaya merupakan sekolah menengah kejuruan yang berada di Jl. Kalijudan Kecamatan Mulyorejo Kota Surabaya. SMK PGRI 4 merupakan sekolah yang salah satu akses menuju sekolah melewati jalan Merr Ir.Soekarno. Mayoritas dari pelajar menggunakan sarana sepeda motor sebagai sarana transportasi utama menuju kesekolah walaupun lokasi sekolah jaraknya yang tidak terlalu jauh dengan tempat tinggal pelajar.

Berdasarkan konsep dari WHO mendefinisikan remaja berdasarkan 3 (tiga) kriteria, yaitu: biologis, psikologi dan sosial ekonomi. Kriteria bilogis dengan contoh berkembangnya individu 
berkembang dengan lebih menunjukkan tanda-tanda seksualitas sekundernya sampai saat dia mencapai kematangan seksual. Perkembangan psikologi dan pola identifikasi dari anak-anak menjadi lebih dewasa, pola identifikasi akan membantu seseroang untuk lebih siap dan matang untuk mengatasi permasalahan secara cepat sehingga dapat membantu mengatasi permasalahan saat berkendara dan lebih bijak dalam berkendara di jalan raya. Sosial ekonomi pada seseorang akan membantu dalam mengatasi ketergantungan dan juga memperisiapkan individu untuk lepas dari ketergantungan dan menjadi lebih mandiri. (Sarwono, 2008).

Pengetahuan atau kognitif merupakan sebuah domain yang sangat penting dalam membentuk tindakan seseorang. Pengetahuan merupakan salah satu faktor yang dapat mendasari seseorang untuk berperilaku dan pengetahuan juga sangat bermanfaat bagi seseorang untuk berperilaku. Berdasarkan penelitian yang dilakukan perwitaningsih dapat diketahui bahwa adanya hubungan dengan praktik keselamatan berkendara saat mengendarai sepeda motor dengan subjek mahasiswa Fakultas Kesehatan Masayarakat Universitas Dian Nuswantoro Semarang. (Perwitaningsih, 2013).

Pengalaman berkendara juga merupakan hal penting yang dapat mempengaruhi keselamatan dari pengendara sepeda motor berdasrkan penelitian yang dilakukan oleh Gineung Utari pada tahun 2010 menunjukkan hasil masa berkendara mempunyai hubungan dengan perilaku keselamatan berkendara sehingga tingkat penguasaan pengetahuan serta keterampilan seseorang dalam pekerjaannya yang dapat diukur dari pengalaman, pemahaman, maupun keterampilan yang dimiliki. Apabila kemampuan pada diri seseorang mengenai berkendara yang aman sangat baik aman maka kejadian kecelakaan lalu lintas dapat diminimalkan. (Utari, 2010).

Berdasarkan undang-undang No 22 tahun 2009 tentang Lalu Lintas dan Angkutan Jalan surat izin mengemudi merupakan sebuah bukti bahwa seseorang telah diizinkan mengendarai jenis kendaraan tertentu oleh pihak kepolisian. Banyaknya pelanggaran lalu lintas dikarenakan tidak memiliki SIM merupakan salah satu penyebab terjadinya kecelakaan lalu lintas yang ada saat ini. Untuk mendapatkan SIM seseorang harus memenuhi persyaratan yang telah ditentukan dan mengikuti ujian yang diadakan oleh Polri. Jika seseorang tersebut telah melewati beberpa persyaratan yang dilakukan oleh Polri maka seseorang tersbut dinyatakan lulus dan diperbolehkan untuk membawa kendaraan sesuai dengan golongan yang tertera dalam SIM, misalnya SIM C yang berarti seseorang boleh mengemudikan kendaraan sepeda motor, sedangkan SIM A berarti seseorang tersebut boleh mengemudikan kendaraan roda empat atau mobil.

Keselamatan berkendara atau juga bisa dikenal dengan istilah safety riding merupakan suatu program untuk menekan angka kecelakaan lalu lintas. Sasaran program safety riding adalah : melengkapi kendaraan dengan spion, lampu sein, dan lampu rem (kelengkapan kendaraan). Menggunakan helm standart dan memastikan berbunyi klik (kelengkapan keselamatan). Menyalakan lampu pada siang hari untuk kendaraan roda dua. Menggunakan lajur kiri bagi penumpang (MPU) dan kendaraan roda dua. (Puspitasari \& Hendrati, 2013).

Berdasarkan petunjuk berkendara oleh Departemen Perhubungan RI tahun 2009 saat mengendarai kedaraan sepeda motor ada beberapa komponen keselamatan berkendara yang perlu diterapkan yaitu, kondisi pengendara yang harus berada pada keadaan baik, orang dengan keadaan sakit tidak disarankan untuk mengemudikan kendaraan bermotor dikarenakan jika kondisi tubuh tidak baik maka akan mempengaruhi tingkat kewaspadaan, kesadaran dan bertingkah laku mengendarai kendaraan akan kurang baik. Perlu memakai alat pelindung diri yang sesuai dengan Standart Nasional Indonesia (SNI) yang telah dimuat dalam UU No 22 Tahun 2009. 
Pemeriksaan komponenen kendaraan merupakan hal sangat penting untuk dilakukan oleh pengendara sepeda motor karena hal tersebut berkaitan dengan keamanan dan kenyamanan saat berkendara. Pemeriksaan sebelum berkendara agar terhindar dari kondisi tak aman (Unsafe condition) saat berkendara. Beberapa hal yang perlu diperhatikan sebelum berkendara yang pertama adalah alat kendali yang meliputi apakah kopling dan gas berfungsi dengan baik dikarenakan alat kendali ini merupakan komponen kendaraan bermotor yang paling utama untuk mengendarai sepeda motor. Periksa rem depan dan rem belakang, pemeriksaan rem memiliki tujuan untuk memastikan rem berkerja dengan baik atau tidak, salah satu penyebab kejadian kecelakaan yang disebabkan oleh rem tidak berfungsi dengan baik atau bahkan tidak berfungsi saat melaju sehingga menyebabkan kecelakaan.

Pemeriksaan perangkat yang lainnya seperti spion sepeda motor apakah sudah dalam posisi yang benar sehingga dapat membantu melihat belakang apabila ingin berbelok ataupun menjaga jarak terhadap pengendara yang lainnya agar tidak memahayakan diri sendiri dan pengendara lain apabila ingin menyalip kendaraan dan ingin berbelok saat di tengah jalan. Pemeriksaan ban sepeda motor perlu dilakukan guna mencegah terjadinya kecelakaan, ban dengan permukaan yang tidak rata merupakan hal yang dapat memahayakan saaat berkendara khususnya pada saat melintas dijalan yang licin. Tapak ban harus memiliki alur kedalaman sedikitnya dalah $1 \mathrm{~mm}$. Tiap ban memiliki indikator tapak ban. Penggunaan ban yang tidak sesuai dengan standart juga dapat membahayakan pengendara terutama dalam penggunaan ban ukuran yang kecil dikarenakan tidak sesuai dengan kekuatan beban yang dimiliki pada ban sepeda motor. Ban sepeda motor juga menjadi penyebab salah satu kecelakaaan lalu lintas di jalan raya. Pemeriksaan komponen yaitu lampu utama, lampu sein dan lampu rem. Komponen tersebut merupakan komponen pendukung untuk memberikan isyarat kepada pengemudi lain mengenai kemana arah kita mengemudikan kendaraan. (Departemen Perhubungan RI, 2009).

Menurut teori Lawrence Green menyatakan bahwa perilaku manusia dipengaruhi oleh dua faktor pokok yaitu faktor perilaku dan juga faktor dari faktor luar perilaku. Perilaku sendiri ditentukan dari 3 faktor yaitu

Faktor predisposisi (Predispocing Factors), yakni faktor-faktor yang mempermudah atau mendahului terjadinya sebuah perilaku pada diri seseorang, antara lain : pengetahuan, persepsi, pengalaman, kepercayaan, nilainilai.

Faktor pemungkin (enabling Factors), yakni faktor-faktor yang memungkinkan atau memfasilitasi perilaku. Faktor pemungkin yang dimaksud adalah sarana dan prasarana atau fasilitas untuk terjadinya perilaku selamat dalam berkendara seperti halnya karakteristik dari pengendara yang mengemudikan kendaraan bermotor harus memiliki Surat Izin Mengemudi (SIMC), adanya dukungan fasilitas kendaraan bermotor, dan peraturan lalu lintas.

Faktor penguat (Reinforcing Factors), yakni faktor-faktor yang memperkuat atau mendorong seseorang untuk berperilaku selamat saat berkendara seperti adanya dukungan dari orang lain untuk melakukan perilaku keselamatan berkendara.

Tujuan dari penelitian ini adalah untuk menganalisis hubungan antara faktor keselamatan berkendara dengan perilaku keselamatan berkendara pada pelajar kelas dua SMK PGRI 4 Surabaya. Kecelakaan lalu lintas tidak dapat di prediksi kapan akan terjadi sehingga perlu adanya perilaku yang aman guna meminimalkan terjadinya kecelakaan lalu lintas yang melibatkan pelajar atau pengendara yang berusia produktif.

\section{METODE}

Jenis dan rancang bangun penelitian ini menggunakan rancang penelitian 
observasional analitik dengan menggunakan pendekatan kuantitatif. penelitian ini menggunakan studi cross sectional.Populasi pada penelitian ini adalah pelajar kelas dua SMK PGRI 4 surabaya sedangkan sampel pada penelitian ini diperoleh menggunakan rumus Slovin. Jumlah responden yang diperlukan pada penelitian ini sebanyak 74 responden, pengambilan sample menggunakan simple random sampling sehingga semua populasi memiliki kesempatan yang sama untuk menjadi sample penelitian.

Variabel bebas dalam penelitian ini meliputi karakteristik yang meliputi usia, kepemilikan SIM C, masa berkendara, pengetahuan. Variabel terikat adalah perilaku keselamatan berkendara.

Data primer pada penelitian ini diperoleh langsung dari responden yang menjadi sampel penelitian dengan menggunkan kuisioner dan data sekunder pada penelitian ini didapatkan dari SMK PGRI 4 Surabaya terkait jumlah pelajar, data dari Satuan Lalu Lintas Kota Surabaya mengenai data kecelakaan sepeda motor, jurnal ilmiah dan internet.

\section{HASIL dan PEMBAHASAN}

Mayoritas dari pelajar SMK PGRI 4 Surabaya menggunakan sepeda motor sebagai sarana transportasi menuju kesekolah dikarenakan minimnya transportasi umum seperti angkot maupun bis yang melewati lokasi dari sekolah.

SMK PGRI 4 Surabaya menerapkan peraturan bahwa setiap kendaraan bermotor yang parkir di area sekolahan wajib memiliki dan membawa STNK.

Berdasarkan penelitian yang dilakukan di SMK PGRI 4 Surabaya didapatkan bahwa mayoritas dari pelajar kelas 2 yang menjadi responden berjenis kelamin lakilaki dengan jumlah responden sebanyak 72 pelajar dan responden yang berjenenis kelamin perempuan ada 2 responden.

Usia dari pelajar kelas dua SMK PGRI 4 Surabaya rata-rata berusia 16,86 tahun. Usia responden yang paling rendah didapatkan pada saat penelitian adalah 16 tahun dan usia responden yang paling tinggi adalah 18 tahun.

Berdasarkan pengambilan data yang dilakukan di SMK PGRI 4 Surabaya, jumlah pelajar yang berusia kurang dari 17 tahun sebanyak 14 responden dan responden yang berusia 17 tahun atau lebih terdapat 60 responden

Berdasarkan data yang diperoleh pada saat penelitian mayoritas responden kelas dua yang mengendarai sepeda motor menuju sekolah masih belum memiliki surat ijin mengemudi (SIM C) dengan 58 pelajar yang masih belum memiliki SIM $\mathrm{C}$ dan yang telah memiliki surat izin mengemudi (SIM C) sebanyak 16 responden.

Berdasarkan data masa berkendara pelajar diketahui bahwa mayoritas dari responden telah mengendarai sepeda motor lebih dari 2 tahun yaitu berjumlah 47 responden dan responden yang baru mengendarai sepeda motor yang berkisar kurang dari atau sama dengan 2 tahun sebanyak 27 pelajar, dengan rata-rata masa berkendara dari responden 2,99 tahun dengan pengalaman berkendara dari pelajar adalah 1 tahun sedangkan pengalaman berkendara yang paling lama adalah 6 tahun.

Berdasarkan hasil pengukuran menggunakan kuisioner diperoleh hasil yang menunjukkan bahwa mayoritas dari responden kelas 2 memiliki pengetahuan keselamatan berkendara yang baik dengan jumlah 46 responden sedangkan responden yang memiliki pengetahuan dengan kategori kurang jumlahnya jauh lebih sedikit yaitu berjumlah 28 responden.

Hasil tersebut membuktikan kebanyakan dari responden mayoritas telah mengerti dan tau akan keselamatan berkendara yang berguna saat mengendarai kendaraan bermotor.

Berdasarkan pengukuran yang dilakukan menggunakan kuisioner kepada 
responden dapat diketahui bahwa responden yang melakukan perilaku aman jumlahnya jauh lebih banyak yaitu 59 responden di bandingkan dengan responden yang tidak berperilaku aman saat berkendara yaitu 15 responden. Hasil dari pengukuran tersebut membuktikan bahwa kebanyakan dari responden lebih memilih untuk melakukan perilaku aman saat berkendara.

Kebanyakan dari responden melakukan perilaku tidak aman yaitu pada saat berkendara mereka tidak membawa SIM dikarenakan belum memiliki SIM dan belum mendaftar serta belum mengikuti ujian SIM sebagai pengendara sepeda motor di Kepolisian RI. Perilaku tidak aman yang memiliki presentase yang tinggi selain SIM adalah pengendara tidak menggunakan Masker sebagai pelindung pernafasan saat berkendara, padahal masker sangat penting untuk melindungi pernafasan dari asap kendaraan bermotor dan juga debu di jalan raya. Maka dari itu peneliti memberikan masker untuk responden penelitian sebagai alat bantu untuk melindungi pernafasan dari asap kendaraan bermotor dan juga debu saat mengendarai sepeda motor.

\section{Tabulasi Silang Antara Karakteristik Responden, Masa Berkendara, Pengetahuan, dengan Perilaku Keselamatan Berkendara.}

Tabel 2. Tabulasi Silang antara Usia dengan Perilaku Keselamatan Berkendara

\begin{tabular}{c|l|c|c|c}
\hline \multicolumn{2}{c|}{} & \multicolumn{2}{|c|}{$\begin{array}{c}\text { Perilaku } \\
\text { Keselamatan } \\
\text { Kerkendara }\end{array}$} & \multirow{2}{*}{ Total } \\
\cline { 3 - 5 } \multicolumn{2}{c}{ Karakteristik } & $\begin{array}{c}\text { Tidak } \\
\text { Aman }\end{array}$ & Aman & \\
\cline { 3 - 5 } \multicolumn{2}{c|}{} & $\mathbf{N}$ & $\mathbf{N}$ & $\mathbf{N}$ \\
\hline \multirow{3}{*}{ Usia } & $<17$ & 2 & 12 & 14 \\
& $\geq 17$ & 13 & 47 & 60 \\
\cline { 2 - 5 } & Total & 15 & 59 & 74 \\
\hline \multirow{3}{*}{ SIM C } & Sudah & 2 & 14 & 16 \\
& Belum & 13 & 45 & 58 \\
\cline { 2 - 5 } & Total & 15 & 59 & 74 \\
\hline
\end{tabular}

Tabel 3. Tabulasi Silang Antara Masa Berkendara dengan Perilaku Keselamatan Berkendara

\begin{tabular}{l|c|c|c}
\hline \multirow{2}{*}{$\begin{array}{c}\text { Masa } \\
\text { Berkendara }\end{array}$} & \multicolumn{2}{|c|}{$\begin{array}{c}\text { Perilaku } \\
\text { Keselamatan } \\
\text { Berkendara }\end{array}$} & \multirow{2}{*}{ Total } \\
\cline { 2 - 3 } & $\begin{array}{c}\text { Tidak } \\
\text { Aman }\end{array}$ & Aman & \\
\cline { 2 - 3 } & $\mathbf{N}$ & $\mathbf{N}$ & $\mathbf{N}$ \\
\hline Baru & 6 & 21 & 27 \\
Lama & 9 & 38 & 47 \\
\hline Total & 15 & 59 & 74 \\
\hline
\end{tabular}

Tabel 4. Tabulasi Silang Antara Variabel Pengetahuan dengan Perilaku Keselamatan Berkendara

\begin{tabular}{l|c|c|c}
\hline \multirow{2}{*}{ Pengetahuan } & \multicolumn{2}{|c|}{$\begin{array}{c}\text { Perilaku } \\
\text { Keselamatan } \\
\text { Berkendara }\end{array}$} & \multirow{2}{*}{ Total } \\
\cline { 2 - 3 } & $\begin{array}{c}\text { Tidak } \\
\text { Aman }\end{array}$ & Aman & \\
\cline { 2 - 3 } & $\mathbf{N}$ & $\mathbf{N}$ & $\mathbf{N}$ \\
\hline Baik & 7 & 39 & 46 \\
Kurang & 8 & 20 & 28 \\
\hline Total & 15 & 59 & 74 \\
\hline
\end{tabular}

Berdasarkan tabel 2 tabulasi silang antara karakteristik yang meliputi usia dengan perilaku keselamatan berkendara menunjukkan bahwa dari 74 responden yang memiliki usia yang kurang dari 17 tahun yang melakukan perilaku keselamatan berkendara yang aman sebesar 12 responden dan memiliki perilaku tidak aman ada sebesar 2 responden. Responden yang berusia lebih dari atau sama dengan 17 tahun yang melakukan perilaku aman sebesar 45 dan perilaku tidak aman sebesar 13 .

Berdasarkan perbandingan usia, responden yang berusia 17 tahun atau lebih jumlahnya lebih banyak di bandingkan dengan usia yang kurang dari 17 tahun dan berdasarkan kategori dari umur tersebut keduanya mayoritas juga melakukan perilaku aman dalam berkendara dengan jumlah responden yang berumur kurang dari 17 tahun 
sebanyak 12 responden dari 14 responden dan 47 responden dari 60 responden.

Berdasarkan hasil analisis uji statistik Chi Square mendapatkan $p$ value $0,721(p>0,05)$. Maka dapat disimpulakn bahwa tidak ditemukan adanya hubungan yang signifikan antara usia dengan perilaku keselamatan berkendara pada responden kelas 2 SMK PGRI 4 Surabaya.

Sedangkan karakteristik responden selanjutnya adalah kepemilikan SIM C dapat diketahui berdasarkan penelitian yang dilakukan di SMK PGRI 4 Surabaya bahwa mayoritas dari responden kelas 2 yang mengendarai sepeda motor belum memiliki surat izin mengemudi golongan $\mathrm{C}$. Berdasarkan tabulasi silang dengan perilaku keselamatan berkendara dapat diketahui bahwa responden yang telah memiliki SIM C tetapi tidak melakukan perilaku amann sebanyak 2 responden, sedangkan pada responden yang belum memiliki SIM C dan juga melakukan perilaku tidak aman sebanyak 13 responden.

Berdasarkan hasil dari analisis $C h i$ Square didapatkan bahwa $p$-value 0,499 maka dapat disimpulkan bahwa tidak ada hubungan yang signifikan antara kepemilikan SIM C dengan perilaku keselamatan berkendara pada pelajar SMK PGRI 4 Surabaya.

Berdasarkan tabel 3. Mengenai tabulasi silang antara masa berkendara dengan perilaku keselamatan berkendara. Dapat diketahui bahwa responden kelas 2 SMK dengan masa berkendara dengan kategori baru yang melakukan perilaku tidak aman jumlahnya jauh lebih sedikit yaitu 6 repsonden yang berperilaku tidak aman dari 27 responden. Sedangkan pada responden yang memiliki masa berkendara yang cukup lama mayoritas dari responden juga memilih untuk melakukan perilaku keselamatan berkendara yang aman dengan jumlah 38 responden dari 47 responden.

Hasil analisis uji statistik menggunakan Chi Square didapatkan bahwa $p$-value 0,987 yang membuktikan bahwa tidak ada hubungan yang signifikan antara masa berkendara dengan perilaku keselamatan berkendara pada pelajar kelas 2 SMK PGRI 4 Surabaya.

Sedangkan pada tabel 4 yang menunjukkan tabulasi silang antara pengetahuan dengan perilaku keselamatan berkendara memiliki hasil responden yang memiliki pengetahuan mengenai keselamatan berkendara baik masih ada yang melakukan perilaku tidak aman, dari total 46 responden yang memiliki tingkat pengetahuan baik masih ada 7 responden yang tidak melakukan perilaku tidak aman. Sedangkan pada responden yang memiliki pengetahuan kurang terdapat 8 responden yang tidak melakukan perilaku tidak aman saat berkendara..

Berdasarkan hasil uji statistik $C h i$ Square antara pengetahuan dengan perilaku keselamatan berkendara didapatkan $p$-value sebesar 1,921 yang membuktikan bahwa angka tersebut lebih besar dari nilai kemaknaan yaitu 0,05 . Sehingga dapat disimpulkan bahwa tidak ditemukan hubungan antara pengetahuan dengan perilaku keselamatan berkendara pada pelajar kelas 2 SMK PGRI 4 Surabaya.

Usia merupakan salah yang dapat mempengaruhi kehidupan seseorang semakin lama usia dari seseorang juga dapat memberikan pengaruh terhadap kehidupan sehari-hari. Usia dapat menentukan kematangan dalam 
mengendarai kendaraan, apakah seseorang tersebut dapat mengendalikan kendaraannya baik secara mental maupun fisik dikarenakan perlu adanya konsentrasi dan juga fisik yang matang untuk mengendalikan laju dari kendaraan.

Berdasarkan data Kepolisian Resort Kota Surabaya didapatkan bahwa pada tahun 2015 dan 2016 terdapat 1.055 kejadian kecelakaan lalu lintas yang melibatkan usia 16 sampai dengan 30 tahun. Berdasarkan hasil penelitian yang dilakukan di SMK PGRI 4 Surabaya usia dari responden paling banyak dalah lebih atau sama dengan 17 tahun dengan jumlah 60 responden.

Kepemilikan surat izin mengemudi adalah hal yang sangat penting dan diwajibkan bagi pengendara kendaraan sepeda motor. hal tersebut telah diatur dalam undang-undang bahwa tahun no 22 tahun 2009 mengenai kepemilikan SIM bagi pengendara kendaraan bermotor. Surat izin mengemudi merupakan surat yang sangatlah penting bagi pengendara sepeda motor sebagai identitas bahwa pengendara telah diijinkan untuk mengendarai kendaraan bermotor sesuai dengan umur dan telah dinyatakan lulus tes SIM yang diberikan oleh kepolisian berdasarkan penelitian yang dilakukan bahwa mayoritas dari pelajar yag mengendarai sepeda motor belum memiliki SIM, sedangkan yang sudah memiliki SIM hanya 16 responden dari 74 responden.

Masa berkendara merupakan hal yang sangat penting bagi setiap orang guna menambahkan pengalaman dan meningkatkan keahlian dalam berkendara seperti kesigapan seseorang dalam menghindari jalan berlubang atau jalan yang tidak rata ataupun mengemudikan kendaraan dimedan yang berlumpur supaya tidak mudah tergelincir saat berkendara. (Khakim, 2016).

Berdasarkan hasil dari penelitian yang dilakukan mayoritas dari responden yang telah mengemudikan sepeda motor dengan kategori lama yang lebih dari 2 tahun sebesar 47 responden dengan rata-rata masa berkendara 2,99 tahun lamanya.

Pada pengetahuan respoden merupakan hal sangat penting dalam menentukan sebuah tindakan seseorang. Pengalaman merupakan salah satu terbentuknya pengetahuan. Pengalaman yang didasari pengetahuan akan lebih baik dariada pengalaman yang tidak didasari oleh pengetahuan dikarenakan pengalaman akan menunjang pengetahuan untuk lebih baik. (Notoadmodjo, 2007).

Hasil dari penelitian menggunakan kuisioner yang membuktikan bahwa 46 responden memiliki pengetahuan baik. Berdasarkan hasil kuisioner didapatkan responden kebanyakan mengetahui bahwa fungsi dari SIM dan STNK hanyalah untuk terbebas dari tilang oleh polisi yang bertugas. Sebenarnya fungsi utama dari surat izin mengemudi atau SIM dan surat tanda nomor kendaraan atau STNK adalah sebagai surat penunjuk bahwa pengemudi memiliki izin yang resmi untuk mengendarai kendaraan bermotor dan fungsi utama dari STNK adalah sebagai penunjuk bahwa kendaraan bermotor tersebut adalah kendaraan yang sah dan bukan hasil barang curian ataupun barang ilegal. (Departemen Perhubungan RI, 2009).

Perilaku merupakan sebuah tindakan atau aktivitas dari manusia yang memiliki arti sangat luas selain berbicara, berjalan, menangis, tertawa dan sebagainya. Perilaku merupakan aktivitas dari makhluk hidup yang dapat diamati langsung maupun 
diamati oleh pihak luar. (Notoadmodjo, 2007).

Perilaku keselmatan berkendara sangat penting untuk diterapkan bagi semua pengendarai kendaraan bermotor guna mencegah terjadinya kecelakaan lalu lintas. Dengan meminimalisirkan kecelakaan lalu lintas maka tingkat kematian di usia produktif akan berkurang. Berdasarkan penelitian yang dilakukan pada pelajar kelas 2 SMK PGRI 4 Surabaya mendapatkan hasil responden yang mengemudikan kendaraan bermotor dengan kategori aman sebanyak 59 responden.

Berdasarkan hasil uji statistik dan tabulasi silang antara usia dengan perilaku keselamatan berkendara tidak ditemukan hubungan yang signifikan antara usia dengan perilaku keselamatan berkendara dengan hasil p-value 0,721 hasil tersebut lebih besar dari nilai kemaknaan yaitu 0,05 maka penelitian dengan faktor usia tidak emiliki hubungan dengan perilaku keselamatan berkendara. Hasil ini membuktikan tidak memiliki kesamaan dengan teori yang menyatakan bahwa usia sesorang dapat mempengaruhi perilaku seseorang dalam berkendara yang aman. (Rukfiati, 2010)

Penelitian ini memiliki kesamaan dengan penelitian sebelumnya yang dilakukan oleh Rizal Khakim (2016) yang mengatakan bahwa tidak ada hubungan yang bermakna antara umur dengan perilaku safety riding pada pengendara ojek di kelurahan Kedungmundu kota Semarang.

Sedangkan hasil dari analsisis uji statistik mengguakan Chi Square berdasarkan kepemilikan surat izin mengemudi dengan perilaku keselamatan berkendara tidak ditemukan adanya hubungan yang signifikan antara kepemilikan SIM dengan perilaku keselamatan berkendara dikarenakan bagi pelajar kelas 2 SMK PGRI surabaya mayoritas dari responden yang memiliki dan tidak meiliki SIM mereka kebanyakan melakukan perilaku keselamatan berkendara yang aman guna meminimalisir resiko terjadinya kecelakaan lalu lintas. Tetapi surat izin lalu lintas merupakan sebuah syarat yang harus dimiliki oleh pengendara dikarenakan untuk membuktikan bahwa pengendara memang layak untuk mengemudikan kendaraan bermotor sesuai dengan golongan SIM

Hasil ini tidak sejalan dengan penelitian yang dilakukan oleh Colle pada tahun 2016 pada siswa SMA Negeri 1 Wundulako yang membuktikan bahwa da hubungan antara kepemilikan SIM C dengan perilaku safety riding dengan p-value 0,041. (Colle, 2016).

Sedangkan pada faktor responden terkait masa berkendara yang dihitung mulai pertama kali responden mengendarai kendaraan bermotor sampai pada saat dilakukan penelitian mendapatkan hasil bahwa mayoritas dari responden telah mengendarai sepeda motor lebih dari 2 tahun. Sedangkan hasil analisis uji statistik menggunakan uji Chi Square menunjukkan hasil p-value 0,987 dengan kata lain hasil tersebut menunjukkan bahwa lebih besar dari nilai signifikansi sehingga dapat disimpulkan bahwa tidak ditemukan adanya hubungan antara masa berkendara dengan perilaku keselamatan berkendara. Memang masa berkendara bukanlah merupakan faktor satu-satunya dalam merubah sebuah perilaku keselamatan berkendara pada seseorang, apabila seseorang tersebut telah melakukan kegiatan mengendarai sepeda motor 
dengan masa berkendara yang cukup lama akan tetapi masih saja melakukan hal yang dapat membahayakan diri sendiri atau orang lain saat mengendarai sepeda motor atau dapat dikatakan melakukan perilaku keselamatan berkendara yang tidak aman mungkin seseorang tersebut terbiasa melakukan perilaku yang tidak aman ataupun faktor lain seperti lingkungan dari pengendara tersebut tyang mendukung bagi pengendara berprilaku yang tidak aman.

Hasil ini tidak sesuai dengan pernyataan yang ada bahwa masa berkendara dapat mempengaruhi perilaku dari seseorang dalam mengendarai kendaraan bermotor yang aman, sebenarnya apabila seseorang yang memiliki pengalam berkendara yang lebih atau mengendarai kendaraan bermotor dengan jangka waktu yang cukuo lama maka seseorang akan mengendarai kendaraan bermotor dengan aman dan sebaliknya apabila seseorang tersebut hanya memiliki pengalaman berkendara yang sedikit maka pengendara akan lebih beresiko untuk melakukan perilaku yang tidak aman. (Notoadmodjo, 2007).

Hasil penelitian ini memiliki
kesamaan
dengan penelitian sebelumnya yang dilakukan oleh Rizal Khakim pada tahun 2016 yang menunjukkan bahwa tidak adanya hubungan antara masa berkendara dengan perilaku safety riding pada pengendara ojek sepeda motor di kelurahan Kedungmundu kota Semarang.

Pada faktor keselamatan berkendara kategori pengetahuan pengendara yang berasal dari pelajar kelas 2 SMK PGRI 4 Surabaya didapatkan hasil bahwa tidak ditemukan adanya hubungan antara pengetahuan dengan perilaku keselamatan berkendara.
Hasil penelitian ini tidak sesuai dengan teori yang menyatakan bahwa pengetahuan seseorang akan mempengaruhi perilaku seseorang dalam berkendara. Semakin baik pengetahuan dari seseorang seharunya akan semakin baik pula perilaku yang dimiliki oleh seseorang saat sedang mengendarai kendaraan bermotor, sebaliknya apabila pengetahuan yang dimiliki seseorang masih kurang maka kemungkinan seseorang berperilaku dalam berkendara juga tidak akan aman. Tidak adanya hubungan antara pengetahuan dengan perilaku keselamatan berkendara keselamatan berkendara memungkinkan ada faktor lain yang lebih mempengaruhi seseorang untuk berperilaku berkendara yanag aman. (Utari, 2010). Akan tetapi hasil penelitian ini memiliki kesamaan hasil pada penelitian pada tahun 2016 yang dilakukan oleh Rizal Khakim yang menyebutkan bahwa tidak ada hubungan antara pengetahuan dengan perilaku safety riding pada pengendara ojek di kelurahan Kedungmundu kota Semarang.

\section{SIMPULAN}

Berdasarkan hasil ditribusi frekuensi dari beberapa faktor keselamatan berkendara yaitu

1. Karakteristik responden yang meliputi usia dan kepemilikan SIM. Di dapatkan hasil bahwa usia responden kelas 2 SMK PGRI Surabaya mayoritas berusia 17 tahun atau lebih, sedangkan berdasarkan kepemilikan SIM C mayoritas dari pengendara kelas 2 belum memiliki Surat Izin Mengemudi.

2. Masa berkendara pada responden didapatkan mayoritas responden telah mengendarai kendaraan bermotor lebih dari 2 tahun, masa berkendara dihitung dari mulai responden pertama kali 
mengendarai sepeda motor hingga saat penelitian.

3. Tingkat pengetahuan responden pelajar kelas 2 SMK PGRI 4 Surabaya mayoritas memiliki pengetahuan keselamatan berkendara dengan kategori baik.

4. Mayoritas dari responden pelajar kelas 2 hanya mengetahui fungsi dari SIM dan STNK hanya untuk bebas terkena tilang oleh pihak kepolisian terutama saat ada razia kendaraan bermotor.

5. Perilaku keselamatan berkendara pada responden mayoritas melakukan perilaku yang aman dalam berkendara.

6. Mayoritas dari pelajar mengendarai sepeda motor tanpa membawa SIM dikarenakan belum memiliki surat izin mengemudi dan belum mendaftarkan diri sebagai pengendara sepeda motor di kepolisian RI.

7. Perilaku yang tidak aman yang selanjutnya adalah tidak memakai masker saat berkendara sehingga dapat membahayakan pernafasan dari pengendara dikarenakan menghirup asap kendaraan dan juga dapat terkena debu.

8. Sedangkan hasil analisis statistik menggunakan Chi Square didapatkan hasil bahwa tidak terdapat hubungan yang signifikan antara usia responden dengan perilaku keselamatan berkendara.

9. Tidak ditemukan adanya hubungan antara kepemilikan SIM $\mathrm{C}$ dengan perilaku keselamatan berkendara

10. Tidak ditemukan hubungan antara masa berkendara dengan perilaku keselamatan berkendara

11. Tidak ditemukan hubungan antara pengetahuan mengenai keselamatan berkendara dengan perilaku keselamatan berkendara

\section{DAFTAR PUSTAKA}

Badan Intelejen Negara, 2012. Kecelakaan lalu Lintas Menjadi Pembunuh Terbesar Ketiga. [Online] Available at: http:/www.go.id/awas/detil/197/4/2103/20 13/kecelakaan-lalu-lintasmenjadipembunuh-terbesar-ketiga

[Accessed 4 April 2017].

Badan Pusat Statistik, 2012. Jumlah Kecelakaan, Korban Mati, Luka Berat, Luka Ringan, dan Kerugian Materi yang Diderita Tahun 1992-2010. [Online] Available at: http://www.bps.go.id/tab_sub/view.php?ta bel=1\&daftar $=1 \&$ id_subyek $=17 \&$ notab $=1$ $\underline{2}$ [Accessed 5 April 2017].

Colle, A.B.A. Dkk., 2016. Faktor-faktor yang berhubungan dengan perilaku safety riding pada siswa SMA Negeri 1 Wundulako Kabupaten kolaka Tahun 2016. Jurnal Kesehatan Masyarakat Universitas Halu Oleo, pp. 1-8.

Dariyo, A., 2004. Psikologi Perkembangan Remaja. Bogor Selatan: Ghalia Indonesia.

Departemen Perhubungan RI, 2009. Buku Petunjuk Tata Cara Bersepa Motor di Indonesia.[Online] Available at: http://dishub.malangkota.go.id/wpcontent/uploads/sites/16/2016/05/BUKUPETUNJUK-TATA-CARABERSEPEDA-MOTOR-DIINDONESIA.pdf.

[Accessed 4 April 2017].

Badan Intelejen Negara, 2012. Kecelakaan lalu Lintas Menjadi Pembunuh Terbesar Ketiga. [Online] Available at: http:/www.go.id/awas/detil/197/4/2103/20 13/kecelakaan-lalu-lintasmenjadi- 


\section{pembunuh-terbesar-ketiga}

Badan Pusat Statistik, 2012. Jumlah Kecelakaan, Korban Mati, Luka Berat, Luka Ringan, dan Kerugian Materi yang Diderita Tahun 1992-2010. [Online] Available at: http://www.bps.go.id/tab_sub/view.php?ta $\underline{\text { bel }=1 \& \text { daftar }=1 \& \mathrm{id} \text { subyek }=17 \& \text { notab }=1}$ $\underline{2}$

[Accessed 5 April 2017].

Colle, A.B.A. Dkk., 2016. Faktor-faktor yang berhubungan dengan perilaku safety riding pada siswa SMA Negeri 1 Wundulako Kabupaten kolaka Tahun 2016. Jurnal Kesehatan Masyarakat Universitas Halu Oleo, pp. 1-8.

Dariyo, A., 2004. Psikologi Perkembangan Remaja. Bogor Selatan: Ghalia Indonesia.

Departemen Perhubungan RI, 2009. Buku Petunjuk Tata Cara Bersepa Motor di Indonesia.[Online] Available at: http://dishub.malangkota.go.id/wpcontent/uploads/sites/16/2016/05/BUKUPETUNJUK-TATA-CARABERSEPEDA-MOTOR-DI-

INDONESIA.pdf.

[Accessed 4 April 2017].

Khakim, R., 2016. Hubungan Antara Umur, Tingkat Pendidikan, Masa Berkendara dan Pengetahuan dengan Perilaku Safety Riding, Skripsi: FKM Universitas Muhammadiyah Semarang.

Notoadmodjo, S., 2007. Promosi Kesehatan dan Ilmu Perilaku. Jakarta: PT Rineka Cipta.
[Accessed 4 April 2017].

Perwitaningsih, R., 2013. Hubungan Antara Pengetahuan Dan Sikap Terhadap Praktik Keselamatan dan Kesehatan Berkendara Sepeda Motor pada Mahasiswa Kesehatan Masyarakat Udinus Semarang, Skripsi: FKM Universitas Dian Nuswantoro.

Polres Kota Surabaya, 2015. Data Kecelakaan di Jalan Ir.Soekarno Tahun 2014, Surabaya: Satuan Lalu Lintas .

Puspitasari, A. D. \& Hendrati, L. Y., 2013. Hubungan Antara Faktor Pengemudi dan Faktor Lingkungan Dengan Kepatuhan Mengendarai Sepeda Motor. Jurnal Berkala Epidemiologi, I(2), pp. 192-200.

Rukfiati, D., 2010. Hubungan Umur, Pengetahuan, Sikap, Dukungan Keluarga, Dukungan teman Kerja dengan Praktik Safety Riding Pada Karyawan Bisnis Development Representatif (BDR), Skripsi: FKM Universitas Diponegoro Semarang.

Sarwono, S. W., 2008. Psikologi Remaja. Jakarta: Raja Grafindo Persada.

Undang-Undang No 22 Tahun, 2009. tentang Lalu Lintas dan Angkutan Jalan. Jakarta, Sekertariat Negara RI.

Utari, G., 2010. Hubungan Pengetahuan, Sikap, Persepsi dan Keterampilan Mengendarai Mahasiswa Terhadap Perilaku Keselamatan Berkendara, Jakarta: Fakultas Kedokteran dan Ilmu Kesehatan UIN Syarif Hidayatullah. 